\title{
Overwinter Mortality of Sympatric Juvenile Bluegill and Yellow Perch in Mid-Temperate Sandhill lakes, Nebraska, U.S.A
}

\author{
Jeffrey C. Jolley ${ }^{1,3,}$, Mark A. Kaemingk $^{1}$, David W. Willis ${ }^{1}$ and Richard S. Holland ${ }^{2}$ \\ ${ }^{1}$ Department of Natural Resource Management, South Dakota State University, SNP 138, Box 2140B, Brookings, South \\ Dakota 57007, U.S.A \\ ${ }^{2}$ Nebraska Game and Parks Commission, P.O. Box 30370, Lincoln, Nebraska 68701, U.S.A \\ ${ }^{3}$ United States Fish and Wildlife Service, Columbia River Fisheries Program Office, 1211 Southeast Cardinal Court, \\ Vancouver, Washington 98683, U.S.A
}

\begin{abstract}
Substantial mortality can occur in age-0 fish populations during their first year of life, especially in winter; this can potentially influence overall recruitment into the adult population. As such, we compared relative abundances between fall and spring catches of sympatric juvenile bluegill Lepomis macrochirus Rafinesque and yellow perch Perca flavescens (Mitchill) to evaluate the magnitude of overwinter mortality across locations (five lakes for two years) and through time (one lake for six years). In addition, we compared both quantile-quantile and increment plots, based on length-frequency histograms from fall- and spring-caught cohorts from 2004 to 2010, to determine if mortality was sizeselective while accounting for over winter growth. Bluegill relative abundances (as indexed by catch-per-unit-effort) significantly decreased from fall to spring, although size-selective mortality was not detected in 10 instances. Yellow perch relative abundances were similar from fall to spring in five Nebraska Sandhill lakes; however, size-selective mortality was detected, with size-selective over winter mortality of smaller individuals occurring in one of eight instances, whereas greater mortality in larger individuals occurred in two instances. Positive growth occurred in both species but was variable among lakes and appeared to be system-specific. In Nebraska Sandhill lakes, over winter mortality likely differs between these two species in its severity, size-selective effect, and scale (i.e., lake-specific vs. large-scale processes), and is likely influenced by combinations of these (and potentially other) factors.
\end{abstract}

Keywords: Bluegill, yellow perch, size-selective mortality, recruitment, over winter growth, shallow lakes.

\section{INTRODUCTION}

The variability in numbers commonly observed in temperate freshwater fish populations (e.g., recruitment variability) likely results in part from environmental stochasticity. For example, recruitment is often variable and year-class strength is often thought to be set in the first year of life for many fishes. Critical time periods of high mortality may exist for some species [1,2], and researchers commonly reference this hypothesis when examining recruitment processes [3]. For both age-0 bluegill Lepomis macrochirus Rafinesque and yellow perch Perca flavescens (Mitchill) this critical period is thought to occur early in cohort development [4-7]. In a more complicated scenario, the effects of bottlenecks of differing intensities may combine in the first year, yielding an additive effect on overall recruitment such that a single well-defined critical period is not evident. For example, Houde [8] reported that subtle shifts in daily mortality and growth together may be ultimately responsible for influenceing recruitment. There are common time periods that are

\footnotetext{
*Address correspondence to this author at the United States Fish and Wildlife Service, Columbia River Fisheries Program Office, 1211 Southeast Cardinal Court, Vancouver, Washington 98683, U.S.A; Tel: (360) 604-2500;
}

Fax: (360) 604-2505; E-mail: jeffrey_jolley@fws.gov often examined for intense mortality events when evaluating the critical time period hypothesis.

For many juvenile fishes, the first winter is often considered to be a critical period [9-14], especially in northern latitudes $[15,16]$. Evidence for size-selective over winter mortality in bluegill populations has been inconsistent, with some studies not finding such evidence $[10,17]$ while others do [18-20]. The over winter mortality that occurs in bluegill populations during the first winter of life may be substantial in some cases, can be strongly linked to predation, but does not always appear to be size-selective [10,17]. These patterns are not commonly assessed simultaneously among sympatric species, and such assessments may provide insight into the variable occurrences of size-selective over winter mortality in bluegill populations.

For yellow perch, in contrast to bluegill populations, size-selective over winter mortality appears to be more pervasive given that larger individuals have a higher probability of surviving to the next life stage (i.e., spring age-1) compared to smaller conspecifics $[15,21]$. The potential causes of these size-related differences include winter severity or how lengthy the periods of reduced temperatures are $[15$, 21]. Specifically, small yellow perch may have higher metabolic demands relative to larger conspecifics, as is found in 
Table 1. Physical Description of Five Study Lakes Located on the Valentine National Wildlife Refuge in North-Central Nebraska

\begin{tabular}{|c|c|c|c|}
\hline Lake & Surface area (ha) & Mean depth (m) & Maximum depth (m) \\
\hline \hline Clear & 79 & 2.1 & 2.4 \\
\hline Dewey & 223 & 1.9 & 2.8 \\
\hline Pelican & 332 & 1.3 & 1.8 \\
\hline Watts & 93 & 1.3 & 1.8 \\
\hline West Long & 25 & 1.3 & \\
\hline
\end{tabular}

other species (e.g., pumpkinseed Lepomis gibbosus (Lacépède) [22]), thus reducing their lipid reserves at a faster rate when resources are limited during winter months [22, 23]. Finally, Higher over winter mortality for age-0 yellow perch has also been related to heightened predation [24]. It is plausible that complex interactions with other species affect the degree of overwinter mortality and whether it is sizeselective.

Recently, Kaemingk et al. [25] and Kaemingk and Willis [26] showed that age- 0 bluegill and yellow perch compete for prey during their first growing season. These interactions resulted in reduced growth for both species, depending on when during the first year of life they are examined. Yellow perch typically hatches two months before bluegill in the Nebraska Sandhill lakes that were studied [27], and age-0 yellow perch can reduce Daphnia biomass prior to the hatch of age-0 bluegill, slowing the growth of the latter [25]. In contrast, age- 0 bluegill abundance negatively affects age- 0 yellow perch growth later in the growing season: when age-0 bluegill densities are high, age-0 yellow perch switches from a mainly macroinvertebrate diet (higher energy) to one dominated by lower-quality prey items (lower energy) such as zooplankton [26]. Previous studies have demonstrated how important it is for fish to reach large size prior to entering the overwinter period $[12,15,18,20,28]$. Consequently, these interactions between yellow perch and bluegill in relation to growth may have consequences for overwinter survival.

We found no studies examining overwinter mortality for sympatric populations of bluegill and yellow perch, even though interactions between them may influence winter mortality. As such, we assessed whether and how overwinter growth and mortality varied for juvenile bluegill and yellow perch over multiple years and across several populations. One lake was studied for six consecutive winters, and four additional lakes were assessed for two consecutive winters; this study design allowed us to quantify the extent of mortality and thus whether size-selective overwinter mortality was pervasive across years and systems for each species. Thus, for sympatric juvenile yellow perch and bluegill populations in Nebraska Sandhill lakes, our specific objectives were to determine 1) the magnitude of overwinter mortality for both species, 2) if mortality was size-selective for these two species, and 3) if spatial and temporal patterns were evident in these size-selective overwinter mortality and growth data.

Finally, from studying patterns in overwinter mortality for both species, we hoped to provide direction for future studies testing the specific mechanisms that regulate first- year recruitment. For example, comparable findings across lakes within years would suggest that abiotic factors (e.g., temperature, winter duration) may overshadow biotic factors for that particular species. Alternatively, finding different population metrics across lakes within a single year would suggest that biotic factors (e.g., predation, food availability) are the main determinants of overwinter mortality, assuming that the lakes differ in their densities of predators or available prey.

\section{MATERIALS AND METHODOLOGY}

\section{Study Area}

Juvenile yellow perch and bluegill samples were obtained from five lakes within the Valentine National Wildlife Refuge in Cherry County of the Sandhills region of north-central Nebraska (Table 1). We monitored Pelican Lake for six consecutive winters (2004/2005 to 2009/2010) and the other lakes (Clear, Dewey, Watts, and West Long) for two winters (2008/2009 and 2009/2010).

The lakes were all within $20 \mathrm{~km}$ of one another, varied in surface area from 25 to 332 ha (Table 1), and were relatively shallow (maximum depth 1.3 to $3.4 \mathrm{~m}$ ). All the lakes were covered extensively by emergent and submergent vegetation [29]. The lake watersheds were primarily mixed- and tallgrass prairie; limited livestock grazing occurred in each [30].

The fish communities were all comprised primarily of bluegill, largemouth bass Micropterus salmoides (Lacépède), yellow perch, northern pike Esox lucius (Linnaeus), black bullhead Ameiurus melas (Rafinesque), and fathead minnow Pimephales promelas Rafinesque. Clear, Dewey, and Pelican lakes also contained abundant common carp Cyprinus carpio Linneaus [31, 32].

Climatological data were obtained from the Miller Field weather station (NOAA), Valentine, Nebraska (40 km north of Pelican Lake), and indicated that winter severity varied across years. We summarized the data to describe winter severity because colder, longer winters with greater snowfall have led to higher probabilities of winterkill [33, 34]. The cumulative number of days when the minimum daily temperature was $\leq 0^{\circ} \mathrm{C}$ (facilitating ice formation) over the entire winter period (from fall cooling to spring warming period) ranged from $130(2009 / 2010)$ to 178 (2007/2008). Winter duration, described as the number of days between the first and last freeze of the winter season, ranged from 213 (2006/2007) to $243(2007 / 2008)$. Cumulative snowfall was greatest in the winter of $2005 / 2006(111.8 \mathrm{~cm})$ and least in 2009/2010 (47.2 cm). 


\section{Magnitude of Overwinter Mortality}

To quantify how much overwinter mortality occurred, we collected juvenile bluegill and yellow perch from the study lakes in August or September (i.e., fall) using three-lobed cloverleaf traps [35], placed in randomly chosen sites in nearshore areas (i.e., not patch type specific) of the lakes in 1-2 $\mathrm{m}$ of water, and checked every $24 \mathrm{~h}$. We then re-sampled the same cohorts the following April or May (i.e., spring) as age-1 fish. Each cloverleaf trap was constructed of galvanized $6.4-\mathrm{mm}$ bar mesh, with three $12.7-\mathrm{mm}$ wide openings between the lobes to allow small bluegill and yellow perch to enter [35]. Each lobe was $50 \mathrm{~cm}$ in diameter and $41 \mathrm{~cm}$ in height. Similar cloverleaf traps have been previously used to assess the stock densities of age- 0 and age- 1 yellow perch in other populations [35] and over a range of fish sizes [36].

Captured juveniles were preserved in $90 \%$ ethanol and returned to the laboratory. Fish collection was conducted under South Dakota State University Institutional Animal Care and Use guidelines. When a length-frequency histogram for the sampled fishes did not allow separation between the age classes, a subsample of fish was aged to distinguish age- 0 from age- 1 fishes in fall, and age- 1 from age2 fishes in spring. Catch-per-unit-effort (CPUE) for age-0 individuals was expressed as the mean number of juvenile fish captured per trap night.

To assess the severity of overwinter mortality, we compared mean CPUE of juvenile bluegill and yellow perch, respectively between the fall and spring samples using repeated measures analysis of variance (ANOVA; MIXED procedure, [37]) with lake as the repeated measure. A significant drop in mean CPUE from fall to spring was considered as evidence that substantial mortality had occurred, whereas the lack of differences would suggest that only modest overwinter mortality had occurred.

\section{Size-selective Overwinter Mortality and Growth}

All fishes were identified to species and measured (TL in $\mathrm{mm}$ ), each species' mean total length was calculated for each season, and length-frequency histograms were constructed for samples with catches of 50 or more individuals. The occurrence of size-selective overwinter mortality was determined by comparing features of the fall and spring lengthfrequency histograms. Size-selective overwinter mortality was evidenced by an increase in mean total length and a reduction in the variance of the survivor sizes (in the absence of growth $[15,38])$. Mean TL was compared between seasons (i.e., fall versus subsequent spring) using Studentized $t$ tests $(\alpha=0.05$ and adjusted depending on variance equality [PROC TTEST]), and coefficient of variation (CV) was qualitatively assessed to describe changes in size through winter (all total lengths were normally-distributed).

In addition, a priori, the occurrence of size-selective mortality was presumed to be difficult to detect if a threshold existed above which mortality rates were constant, and if a subset of fish in the population in a given year exceeded than that size. To this end, we qualitatively truncated our lengthfrequency histograms by excluding bluegill greater than 60 $\mathrm{mm}$ and yellow perch greater than $90 \mathrm{~mm}$ TL, (i.e., the upper tail of the length-frequency distributions), because these fish could occlude the interpretation of the histograms [39].
To partition the effects of potential growth and sizeselective mortality across the winter, we employed empirical quantile-quantile (QQ) and increment plots [15, 40], a combined approach that has been applied to a variety of species [41-45]. For the QQ plots, total length at quantiles 1, 5, 10, $25,50,75,90,95$, and 99 of the size distribution was determined from the length-frequency histograms (i.e., when $n>$ 50 ; [46]) for the fall and subsequent spring samples, and were plotted against each other. A 1:1 reference line (slope = 1) was used to signify proportional (i.e; equivalent) growth between the fall and subsequent spring samples [15].

To construct the increment plots, the incremental differences between the lengths of fall and subsequent spring quantiles were plotted as a function of the corresponding fall quantiles and a linear regression was fitted. The slope of each QQ or increment plot was tested for whether it differed significantly $(\alpha=0.05)$ from 1.0 (QQ plot) and 0.0 (increment plot) using the REG procedure in SAS [37].

For interpretation, a QQ plot with a slope $<1.0$, and an increment plot with negative slope and positive deviations from the 1:1 line, together would be evidence of sizeselective overwinter mortality. Large differences between the smallest quantiles would result from the smallest fish being under-represented in the spring. A QQ plot with a slope > 1.0 would indicate size-dependent growth, with larger individuals gaining incrementally more overwinter length than smaller individuals. A QQ plot with a negative slope and increment values $>0$ would result from size-selective overwinter mortality of the smaller individuals. A QQ plot with a slope $>1.0$ and increment values $>0$ would result where size-dependent growth occurred and larger individuals gained more length than did smaller individuals, a pattern often observed in nature [47-50]. Other scenarios, including no growth between sampling periods, size-dependent mortality of large fish, and faster growth of smaller fish, although rare in nature, could also be identified using this analysis approach [15]. Finally, more complicated scenarios in which size-dependent growth and mortality co-occur can also be identified this way; Post and Evans [15] provided a thorough interpretation of all the possible scenarios.

\section{Patterns in Mortality and Growth}

Evidence of a relation between fall and spring relative abundance across lakes was sought by relating mean fall CPUE to subsequent spring CPUE for bluegill and yellow perch using Pearson's correlation analysis. For interpretation, a significant correlation would result from inter-annual and inter-lake mortality being similar, whereas a nonsignificant relationship would suggest that inter-annual and inter-lake mortality was more variable. If fall and spring CPUE values are correlated, large-scale factors (i.e., abiotic) are more apt to be involved because mortality across the years and lakes would be more consistent. Alternatively, a lack of correlation would suggest that system-specific factors are likely more important, because relative abundance or mortality varies appreciably between years and lakes. We tested for the existence of such patterns in size-selective overwinter mortality and growth each year for all lakes (bluegill $=10$ lake-years; yellow perch $=8$ lake-years; $\alpha=$ 0.05 for all statistical analyses). 
Table 2. Mean Catch-Per-Unit-Effort (CPUE; Number Per Cloverleaf Trap Night) of Juvenile Bluegill and Yellow Perch with Associated Standard Errors and Numbers of Trap Nights in Parentheses, Respectively, in Nebraska Sandhill lakes, 2004-2010

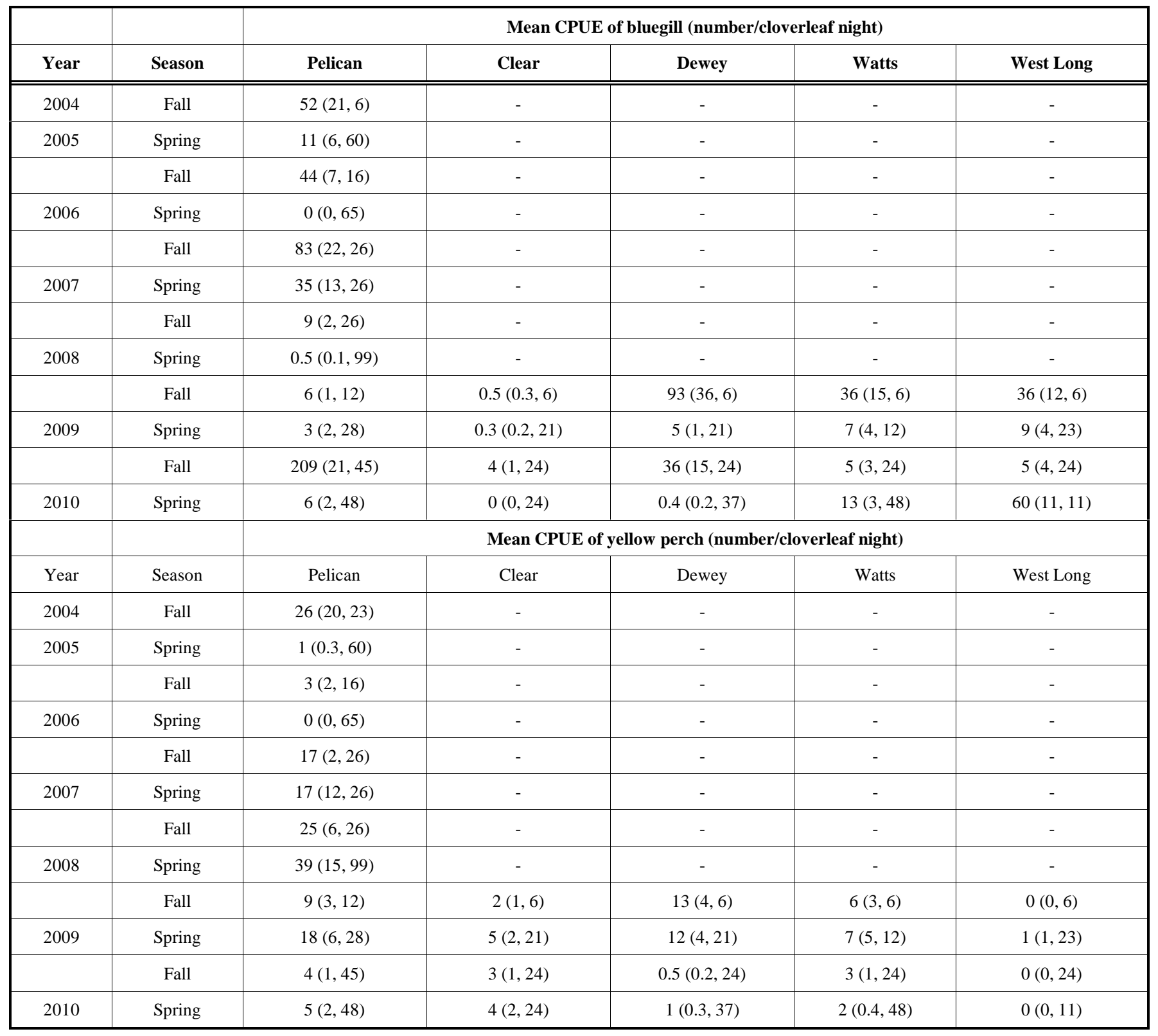

\section{RESULTS}

\section{Magnitude of Overwinter Mortality}

Collections of juvenile bluegill and yellow perch in cloverleaf traps in all lakes was highly variable among years in fall and spring (Table 2). For bluegill, mean CPUE ranged from 0.5 to 209 fish/trap night in the fall and from 0 to 60 fish/trap night in the spring. For yellow perch, mean CPUE ranged from 0 to 26 fish/trap night in the fall and from 0 to 39 fish/cloverleaf night in the spring (Table 2).

Overwinter mortality for bluegill was significantly higher than for yellow perch, given that the bluegill fall CPUE $($ mean $=41.3$, S.E. $=14.7)$ was much higher than in the subsequent spring $\left(\right.$ mean $=10.7$, S.E. $=4.5 ;$ RMANOVA, $F_{1,26}$ $=4.29, P=0.05)$. In contrast, yellow perch overwinter mor- tality appeared to be much lower, given that their fall CPUE $($ mean $=7.9$, S.E. $=2.4)$ did not differ significantly from those in the spring $\left(\right.$ mean $=7.9$, S.E. $=2.9 ;$ RMANOVA, $F_{1}$, ${ }_{26}=0.00, P=0.99$ ). Catch rates for bluegill and yellow perch in Pelican Lake were too low in the spring of 2006 to permit further fall versus spring comparisons (Table 2).

\section{Size-selective Overwinter Mortality and Growth}

For bluegill, the slopes of the QQ plot regression lines were greater than 1.0 , and the increment plot slopes were greater than 0.0 in the same seven of 10 fall versus successive spring seasonal comparisons (Fig. 1). In all 10 instances, the response of the QQ plot regression line was to depart increasingly from the 1:1 line as individuals became larger. For the increment plots, all increments were positive for the same seven of 10 comparisons (Fig. 1). Together, these re- 


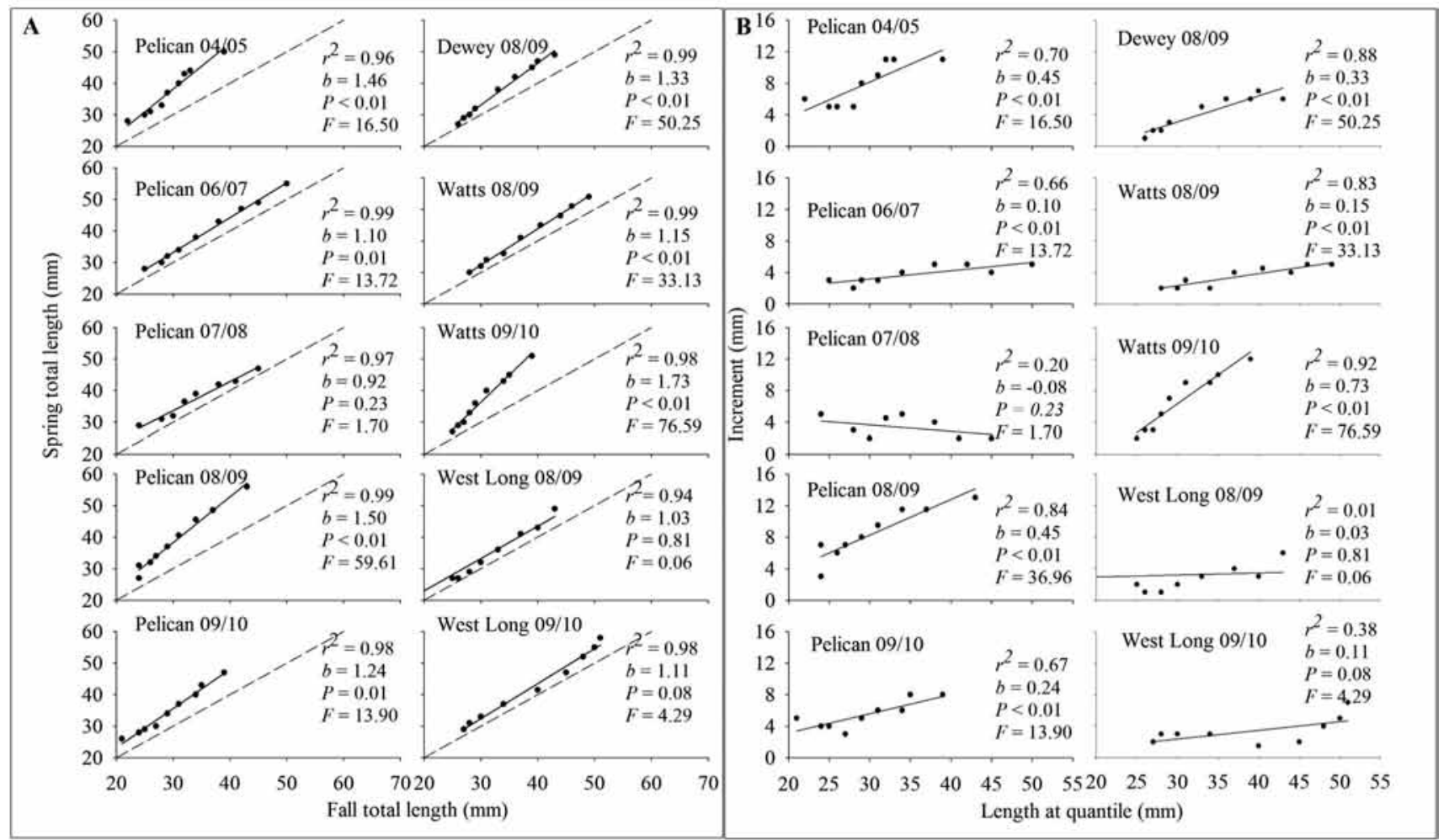

Fig. (1). Empirical length-frequency quantile-quantile plots (A) and increment plots (B) for juvenile bluegill in Nebraska Sandhill lakes, 2004-2010. The solid line is the least squares regression for each cohort, and the broken line is the 1:1 relationship. Coefficients of determination $\left(r^{2}\right)$ and regression slopes $(b)$ are listed; $P$-values and $F$ statistics assess slope differences $(\mathrm{b} \neq 0.0)$.

sults are indicative of juvenile bluegill populations exhibiting overall growth across all sizes, with larger fish growing faster than smaller fish, but with no evidence of sizeselective mortality. The slopes of the remaining three plots for bluegill (Fig. 1) did not differ significantly from 1.0 (QQ plots) and 0.0 (increment plots) (Pelican Lake 2007/2008, West Long Lake 2008/2009), also consistent with the absence of size-selective overwinter mortality. In these three cases, the QQ regression lines lie above but essentially parallel to the 1:1 line, meaning that the incremental change in length was similar across the size ranges.

Mean total length of juvenile bluegill ranged from 29 to $39 \mathrm{~mm}$ in the fall and from 33 to $42 \mathrm{~mm}$ in the spring (Table 3). All $t$-tests indicated significant overwinter increases in total length from fall to spring while variability (i.e., CV) in mean total length was similar or unchanged from fall to spring (Table 3). The length-frequency histograms confirm that growth typically occurred between seasonal sampling given that most of the distributions shifted to the right (Fig. 2, 3). This explains why some of the lengthfrequency distributions spanned a greater length range in the spring compared to the previous fall (Fig. 2, 3). Bluegill growth did occur in Pelican Lake 2007/2008, Watts Lake 2008/2009, and West Long Lake 2008/2009 between sampling occasions, but the incremental changes in length were uniform across the size ranges (Fig. 1).

For yellow perch, the slope of the QQ regression plots was less than 1.0 in three of eight between-season comparisons. The slopes of the respective increment plots were less than 0.0 in the same three cases (Fig. 4), consistent with mortality having been size-selective. In Pelican Lake (2007/2008), the QQ plot slope was less than 1.0, the increment plot slope was less than 0.0 , and the deviations from the increment plot were positive. Together, these indicate that overwinter growth occurred; but because fish in the smallest quantiles from the spring distribution were underrepresented, this mortality appears also to have been sizeselective. The QQ and increment plots from Pelican Lake (2008/2009) and Dewey Lake (2008/2009) show a similar pattern, except that the QQ plot intersects the 1:1 line and the increment plot contains a mix of both positive and negative deviations, the latter being consistent with a more complex causal scenario. This pattern suggests a co-occurrence of higher mortality in larger yellow perch accompanied by growth, given that some of the increments were positive and a consequence of increases in length.

Across the sites and years, the mean total lengths of juvenile yellow perch ranged from 45 to $87 \mathrm{~mm}$ in the fall and from 59 to $99 \mathrm{~mm}$ in the subsequent spring (Table 4). All but one $t$-test indicated that mean total length increased significantly from fall to the subsequent spring. The coefficient of variation $(\mathrm{CV})$ almost always decreased from fall to spring (Table 4), and the length-frequency histograms indicated that overwinter growth usually occurred given that the distributions often shifted to the right (Fig. 5, 6). In one instance (i.e., Watts 2009/2010) the QQ plot slope was > 1.0, the increment plot slope was $>0.0$, and the deviations were positive; together, these are indicative of size-dependent growth. The increment plot slopes did not differ from 0.0 in four 
Table 3. Mean Total Length (TL) (with Associated Standard Errors and N Samples in Parentheses) for Bluegill Sampled with Cloverleaf Traps in Nebraska Sandhill Lakes, 2004-2010. Results of Fall to Subsequent Spring Comparisons of mean TLs are given by $t$ Statistics, Degrees of Freedom $(d f)$, and $P$ Values

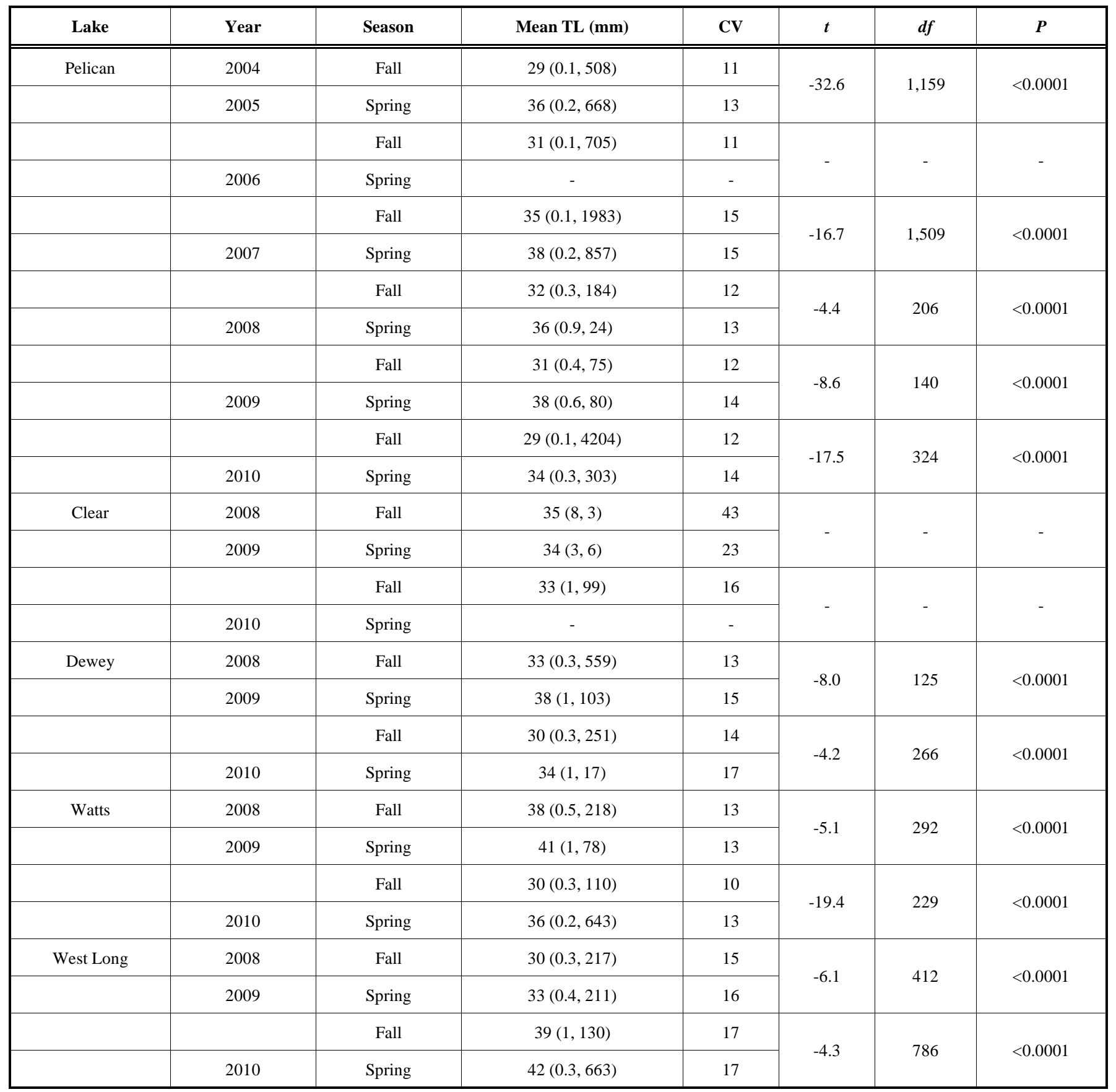

cases, indicating that overwinter growth had occurred but that the incremental changes in length were similar across the size spectra (Fig. 4).

\section{Patterns of Mortality and Growth}

For bluegill, the fall and spring CPUEs were not significantly correlated ( $r=-0.12, P=0.70$; Fig. 7). Bluegill sizeselective overwinter mortality was not evident in any of the lakes we examined for any year, and patterns of overwinter bluegill growth were not synchronous across lakes within any of the years we examined (Fig. 1).
For yellow perch, fall and spring CPUEs were significantly correlated $(r=0.64, P=0.01$; Fig. 7). Size-selective overwinter mortality was similar in two lakes in two years, suggesting synchrony (Fig. 4). Size-dependent growth appeared to be system-specific, given that the growth patterns were not synchronous across lakes within each of the years we examined (Fig. 4).

\section{DISCUSSION}

This study documents the first attempt to explore the extent of overwinter mortality in sympatric bluegill and yellow 


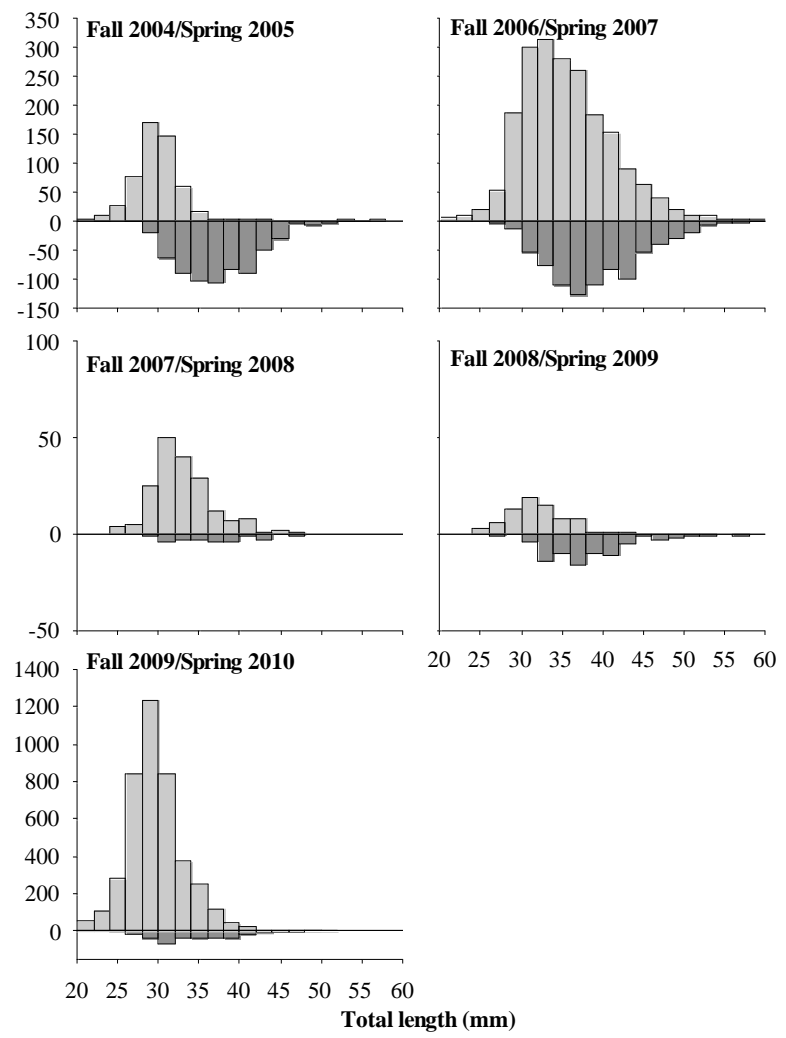

Fig. (2). Fall and subsequent spring size distributions of bluegill from the 2004, 2006, 2007, 2008, 2009, and 2010 year classes captured in cloverleaf traps at Pelican Lake, Nebraska. Y axis counts increase upward from 0 for the fall and downwards from 0 for the following spring.

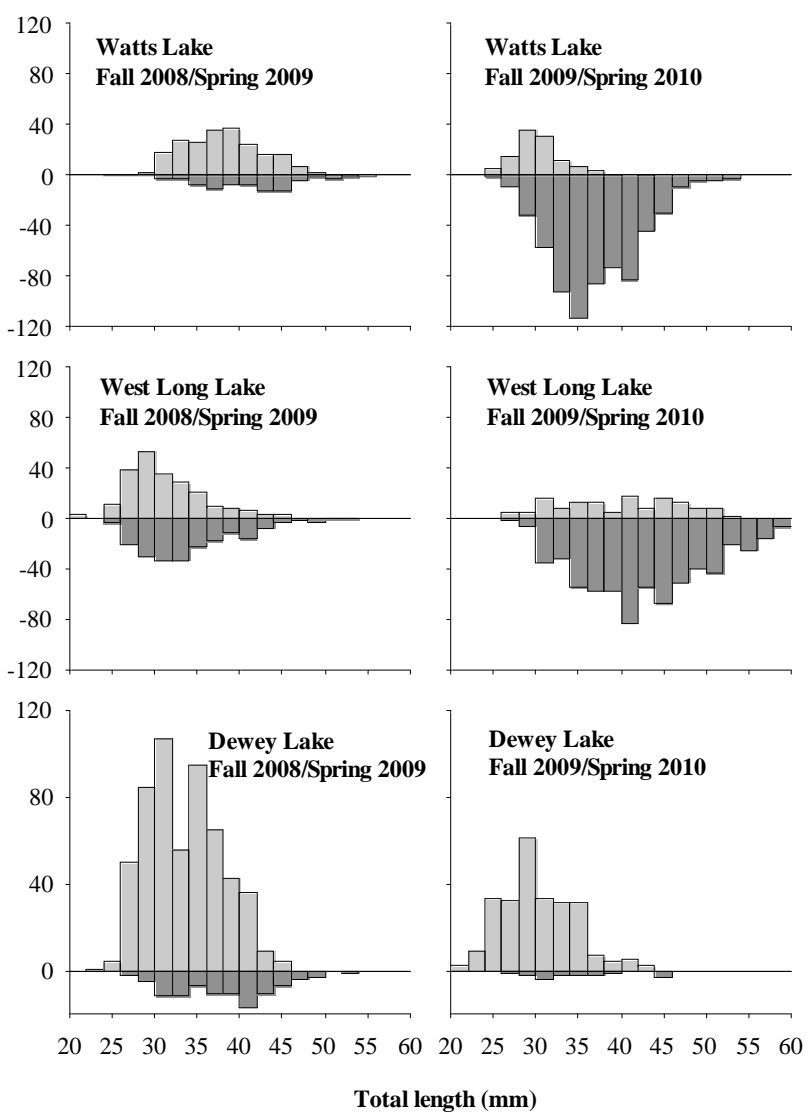

Fig. (3). Fall and subsequent spring size distributions of bluegill from the 2008 and 2009 year classes captured in cloverleaf traps at Watts Lake, West Long Lake, and Dewey Lake, Nebraska. Y axis counts increase upward from 0 for the fall and downwards from 0 for the following spring. 


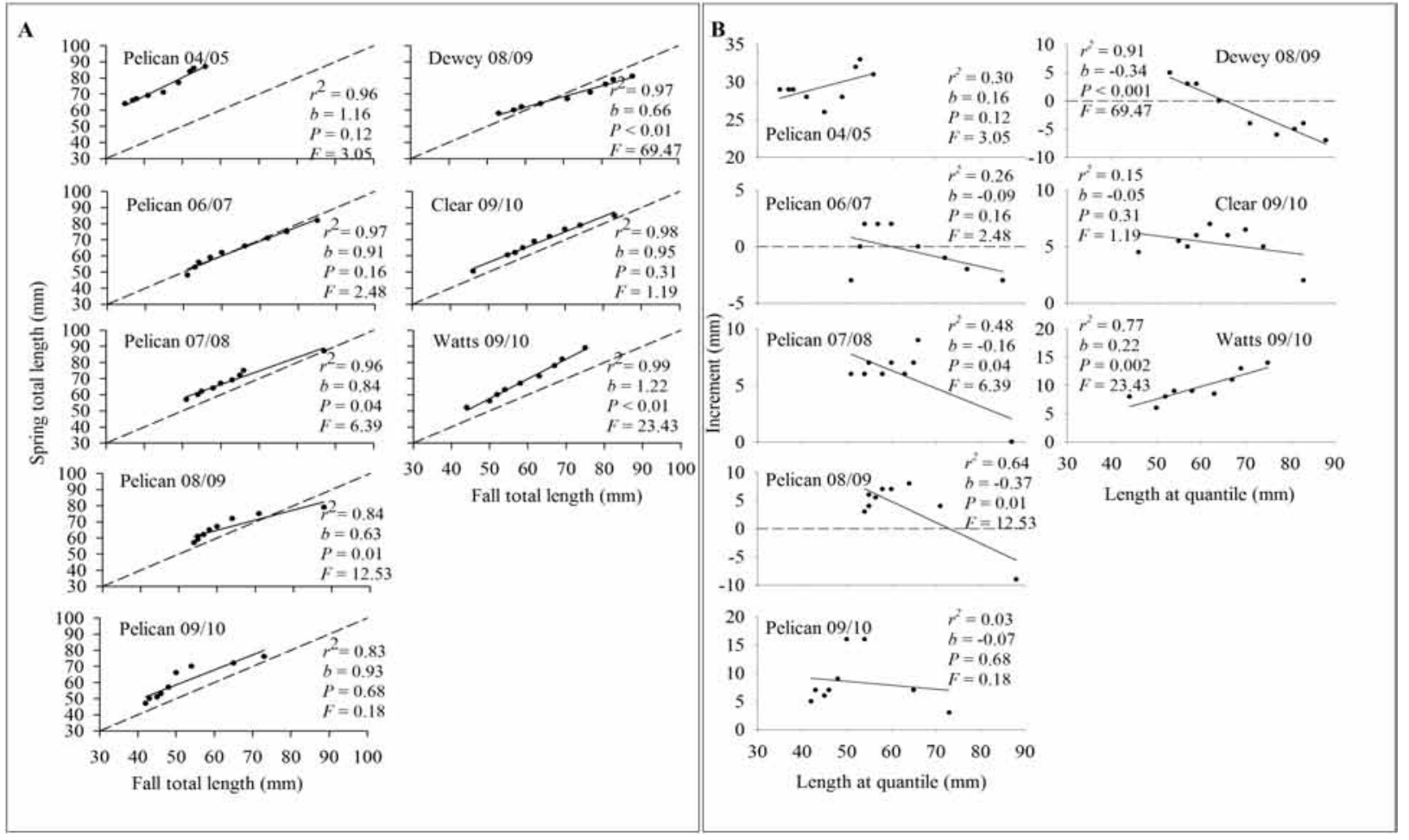

Fig. (4). Empirical length-frequency quantile-quantile plots (A) and increment plots (B) for juvenile yellow perch in Nebraska Sandhill lakes, 2004-2010. The solid line is the least squares regression for each cohort, and the broken line is the 1:1 relationship. Coefficients of determination $\left(r^{2}\right)$ and regression slopes $(b)$ are listed; $P$-values and $F$ statistics assess slope differences $(\mathrm{b} \neq 0.0)$.

Table 4. Mean Total Length (TL) (with Associated Standard Errors and N Samples in Parentheses) of Yellow Perch Sampled with Cloverleaf Traps in Nebraska Sandhill lakes, 2004-2010. Results of Fall to Spring Comparisons of Mean TLs are given by $t$ Statistics, Degrees of Freedom $(d f)$, and $P$ Values

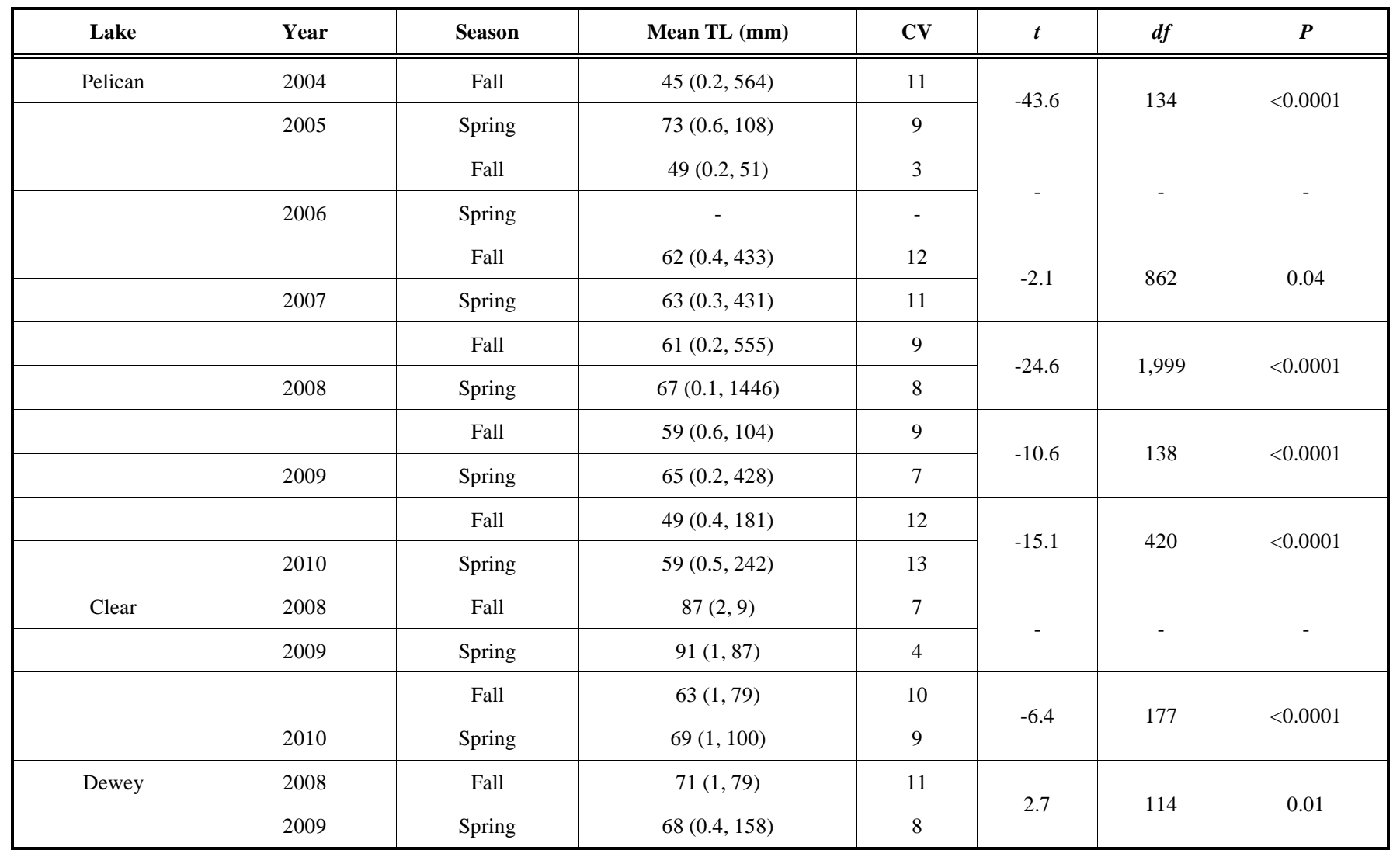


Table 4. contd...

\begin{tabular}{|c|c|c|c|c|c|c|c|}
\hline Lake & Year & Season & Mean TL $(\mathbf{m m})$ & $\mathrm{CV}$ & $t$ & $d f$ & $P$ \\
\hline & & Fall & $56(2,13)$ & 10 & \multirow{2}{*}{-} & \multirow{2}{*}{-} & \multirow{2}{*}{-} \\
\hline & 2010 & Spring & $65(1,54)$ & 12 & & & \\
\hline \multirow[t]{4}{*}{ Watts } & 2008 & Fall & $64(3,36)$ & 8 & \multirow{2}{*}{-6.2} & \multirow{2}{*}{111} & \multirow{2}{*}{$<0.0001$} \\
\hline & 2009 & Spring & $66(1,80)$ & 8 & & & \\
\hline & & Fall & $59(1,66)$ & 10 & \multirow{2}{*}{-8.5} & \multirow{2}{*}{160} & \multirow{2}{*}{$<0.0001$} \\
\hline & 2010 & Spring & $68(1,96)$ & 11 & & & \\
\hline \multirow[t]{4}{*}{ West Long } & 2008 & Fall & - & - & \multirow{2}{*}{-} & \multirow{2}{*}{ - } & \multirow{2}{*}{-} \\
\hline & 2009 & Spring & $99(1,26)$ & 1 & & & \\
\hline & & Fall & $78(-, 1)$ & - & \multirow{2}{*}{-} & \multirow{2}{*}{-} & \multirow{2}{*}{-} \\
\hline & 2010 & Spring & - & - & & & \\
\hline
\end{tabular}
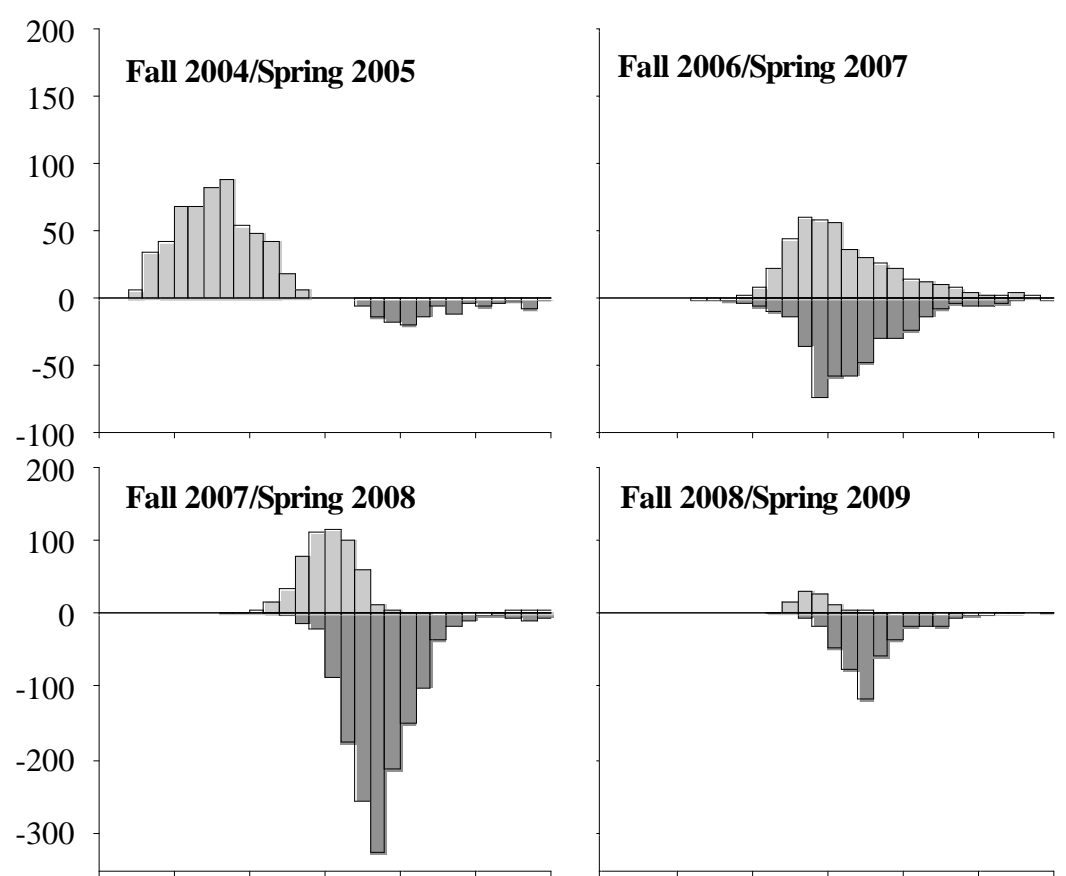

Fall 2008/Spring 2009

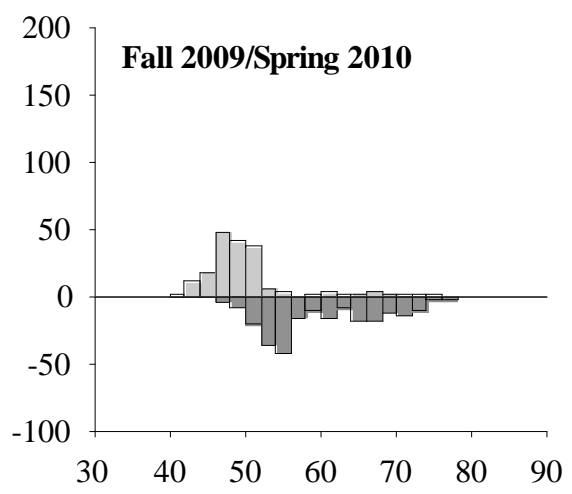

Total length (mm)

Fig. (5). Fall and subsequent spring size distributions of yellow perch from the 2004, 2006, 2007, 2008, and 2009 year classes captured in cloverleaf traps from Pelican Lake, Nebraska. Y axis counts increase upward from 0 for the fall and downward from 0 for the following spring. 

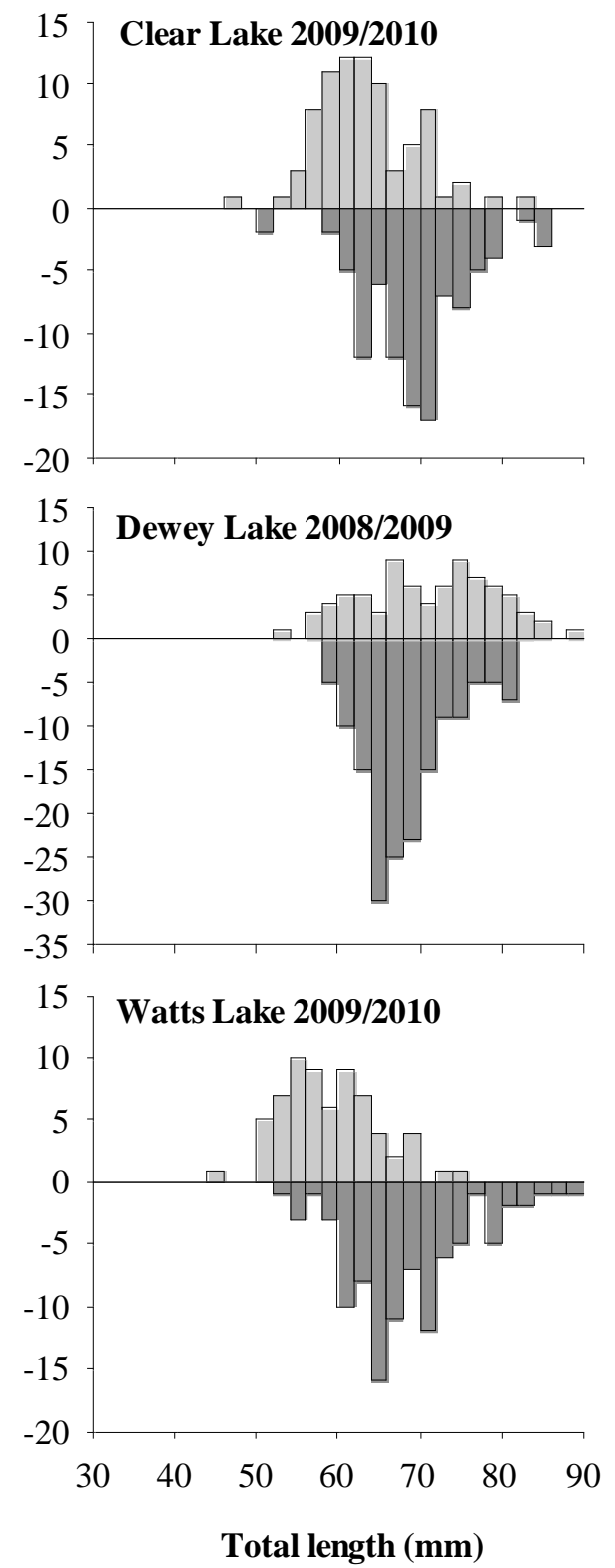

Fig. (6). Fall and subsequent spring size distributions of yellow perch from the 2008 and 2009 year classes captured in cloverleaf traps from three Sandhills lakes, Nebraska. Y axis counts increase upward from 0 for the fall and downward from 0 for the following spring.

perch populations, and to determine if the source of mortality was size-selective. The degree of overall overwinter mortality appeared to be more substantial for bluegill compared to yellow perch in Nebraska Sandhill lakes. Our results, and those of Santucci and Wahl [17] and Shoup and Wahl [20], indicate that substantial mortality can occur during winter months for juvenile bluegill. Furthermore, we infer the large decreases in bluegill CPUE between seasons to be indicative of overwinter mortality. In contrast, the combined mean yellow perch CPUE was not significantly different between seasons in these populations, indicating that the severity of overwinter mortality was not as pronounced in this species. The latter results differ from other studies that found substantial overwinter mortality (44-99\%) for juvenile yellow perch of similar sizes entering their first winter $[15,24,51]$.
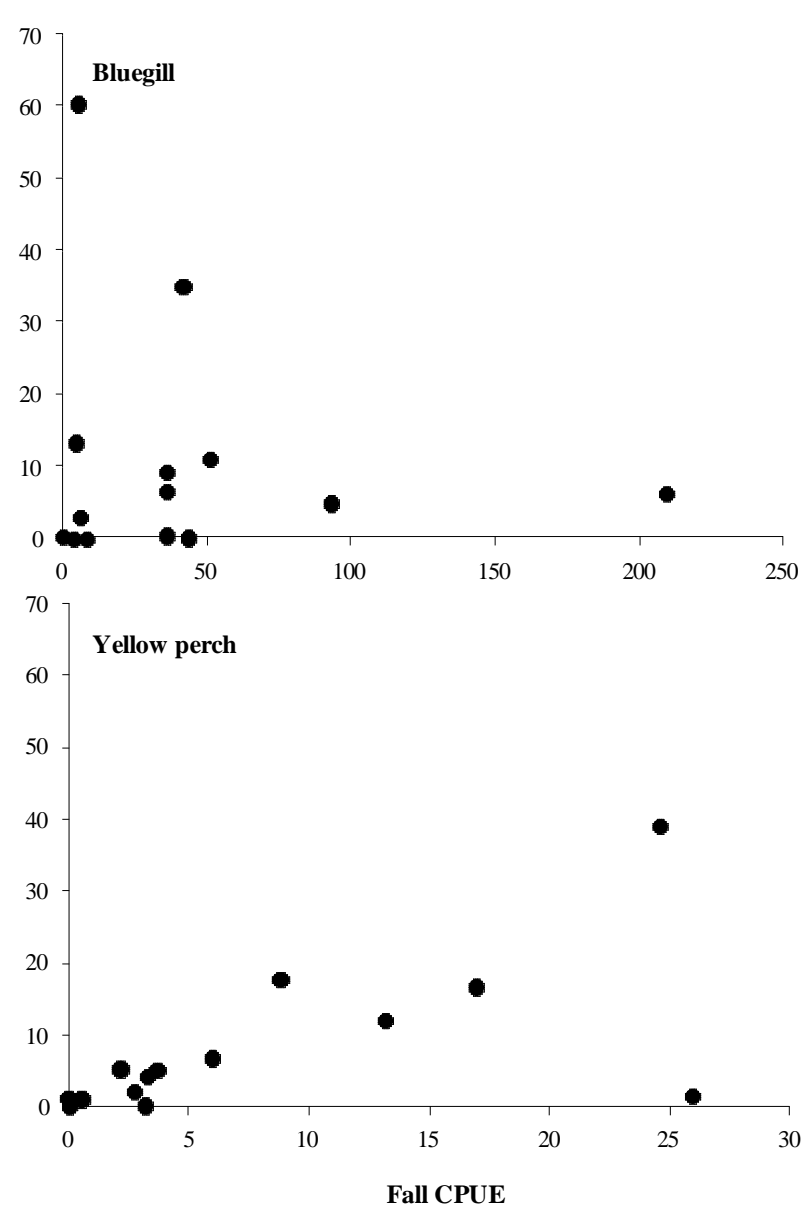

Fig. (7). Mean fall bluegill (top) and yellow perch (bottom) catch/cloverleaf trap night (catch-per-unit-effort [CPUE]) related to mean subsequent spring CPUE in five Nebraska Sandhill lakes.

To estimate the magnitude of overwinter mortality, we compared relative abundances (CPUEs) between our fall and subsequent spring samples. The validity of this approach assumes that substantial mortality would be reflected by a statistically significant decrease in relative abundance between the seasons, and that the absence of a statistical difference would be indicative of moderate to low between-season mortality. The fact that we did not catch significantly higher numbers of fish in the spring compared to the preceding fall for either species (N.B., it was not possible to have more fish entering the population during the overwinter period), supports the notion of minimal catchability differences between the seasons. Previous research in these lakes indicated that age-0 bluegill and yellow perch exhibit substantial habitat overlap during the fall [26] and other studies demonstrate that both species use near-shore habitat during spring or early summer [52-54]. In addition, cloverleaf traps have previously been used to assess the relative abundances of age- 0 and age-1 yellow perch [35], to evaluate the habitat use of other juvenile fishes elsewhere [55], and to effectively catch fish of a range in sizes [36, 55]. This gear was selected for the habitats in these lakes as effective at providing as unbiased a sample as possible of the juvenile fish populations.

For the bluegill in our study, overwinter mortality did not appear to be size-selective. Other studies have also found little evidence of size-selective overwinter mortality for 
bluegill [10, 17]. This phenomenon may thus be systemspecific for bluegill, given that Cargnelli and Gross [18] and Garvey et al. [19] found contrasting evidence of larger individuals being better represented in spring samples, consistent with size-selective overwinter mortality having occurred. Shoup and Wahl [20] also demonstrated the latter experimentally for bluegill, and related this finding to prey (i.e., bluegill) and predator (i.e., largemouth bass) population size structuring; however, it should be noted that almost all the juvenile bluegill sampled in our study were much smaller than Shoup and Wahl's [20] "large" age-0 bluegill size class (40-65 mm TL). None of the bluegill populations evaluated in our study had a mean TL $>40 \mathrm{~mm}$ before winter. Thus, it seems plausible that the juvenile bluegill in our lakes did not exceed the gape size limitations of their predators, dampening the probability of size-selective mortality, as all fish were likely susceptible to predation.

For our yellow perch, size-selective overwinter mortality in smaller fish was found in one study lake (Pelican 07/08) and in larger fish in two study lakes (Dewey and Pelican lakes 08/09). Size-selective overwinter mortality in yellow perch may not occur simultaneously across Sandhill lakes: it thus may result from synergistic interactions amongst winter severity, small size entering the winter period (a result of competition with bluegill, [26]), and predation. Interestingly, our study found higher mortality in larger versus smaller juvenile yellow perch. The winter period during 2009/2010 appeared to be shorter and milder (130 freeze days, $37.2 \mathrm{~cm}$ of cumulative snow) compared to the 2008/2009 winter period (160 freeze days, $79.8 \mathrm{~cm}$ of cumulative snow). This is relevant because size-selective mortality in other yellow perch populations has been linked to increased metabolic demands on stored energy reserves or size-selective predation, which affect smaller individuals to a greater degree [21]. However, Nebraska Sandhill winters are less severe than in those more northerly locations where size-selective mortality affects smaller individuals; thus, the metabolic costs in these Nebraska lakes may be lower.

With comparatively lower energetic costs for surviving the winter, the larger yellow perch in our Nebraska lakes might be at a greater risk of predation because of their higher visibility (i.e., larger body size) and thus may attain sizes that optimize predator foraging later in the year compared to other populations (caused in part by slow growth experienced during the summer; [26]). Both lakes where this occurred contain abundant populations of predatory largemouth bass and northern pike, and it is plausible that large juvenile yellow perch could be selectively targeted and consumed. However, predator-induced size-selective mortality in larger individuals is a less-observed phenomenon [56, 57]. Sizeselective overwinter mortality, in contrast, is commonly found among yellow perch populations [15, 21, 24], but is not always pervasive [58] and typically does not reduce the survival of larger conspecifics as we found in the current study, which suggests a different mechanism (i.e., predation).

Overwinter growth was system-specific for both bluegill and yellow perch, given that results differed between lakes within a given year. Juvenile bluegill in other systems exhibit overwinter growth $[17,19]$, but this is less-well docu- mented for yellow perch [15]. System-specific growth could be attributed to differences in the availability of prey within each lake; this can vary substantially across Sandhill lakes $[27,59,60]$. Size-dependent growth occurred in both bluegill and yellow perch populations, with larger individuals experiencing a greater increase in length than smaller conspecifics. This growth differential may be related to intraspecific competition or gape limitation, where larger conspecifics outcompete or consume larger prey than do smaller counterparts [61-63] during winter when resources are limiting.

Information regarding overwinter mortality in these two species in sympatry is scarce; this study demonstrates that overwinter mortality differed between these two species and that the factors associated with mortality were independent of size for bluegill and could be size-dependent for yellow perch. Mechanistically, overwinter mortality in juvenile bluegill in Nebraska Sandhill lakes is substantial (given that CPUEs were significantly lower in the spring than in the fall), but does not act in a size-selective manner, and potentially acts independently among lakes (given no relationship between fall age-0 spring age-0 CPUEs). Alternatively, the mechanism(s) that might determine juvenile yellow perch overwinter mortality in Nebraska Sandhill lakes may not exert strong effects (given that CPUEs were similar between fall and spring), but instead may act in a size-selective manner.

Based on our findings, future research on sympatric bluegill and yellow perch populations might consider examining in bluegill the role of biotic or system-specific factors such as predation and, in yellow perch, abiotic or large-scale processes such as winter severity. Both species are likely influenced by both abiotic and biotic factors during the overwinter period, but the impacts of these effects may differ between the species. The role of competitive interactions experienced prior to entering the winter [25, 26] should also be examined, especially in yellow perch, which may not reach sufficient sizes to endure the overwinter period. Because the specific factors associated with winter mortality were not identified in this study, future research to isolate and identify these mechanisms in other sympatric bluegill and yellow perch populations are warranted; how these factors impact the two species likely differs.

\section{CONFLICT OF INTEREST}

The authors confirm that this article content has no conflicts of interest.

\section{ACKNOWLEDGEMENTS}

We thank numerous technicians for field and laboratory assistance. M. Lindvall and the Valentine National Wildlife Refuge provided access to the lakes. We thank D. Graham, D. Hartmann, D. Kruger and the Valentine State Fish Hatchery for assistance. Funding for this project was provided by the Nebraska Game and Parks Commission through Federal Aid in Sport Fish Restoration Project F-118-R. The findings and conclusions in this manuscript are those of the authors and do not necessarily represent those of the U.S. Fish and Wildlife Service. 


\section{REFERENCES}

[1] Hjort J. Fluctuations in the great fisheries of northern Europe viewed in the light of biological research. Rapp Reun. CIEM 1914; 20: 1-228.

[2] May RC. Larval mortality in marine fishes and the critical period concept. In: Blaxter JHS, Ed. The Early Life History of Fish. New York; Springer-Verlag 1974; pp. 1-19.

[3] Marr JC. The "critical period" in the early life history of marine fishes. J Cons Int Explor Mer 1956; 21: 160-70.

[4] Toetz DW. Change from endogenous to exogenous sources of energy in bluegill sunfish larvae. Invest Indiana Lakes Streams 1966; 7: 115-46.

[5] Forney JL. Development of dominant year classes in a yellow perch population. Trans Am Fish Soc 1971; 4: 739-49.

[6] Clady MD. Influence of temperature and wind on the survival of early stages of yellow perch, Perca flavescens. J Fish Res Board Can 1976; 33: 1887-93.

[7] Anderson MR, Fisher SJ, Willis DW. Relationship between larval and juvenile yellow perch abundance in eastern South Dakota glacial lakes. North Am J Fish Manage 1998; 18: 989-91.

[8] Houde ED. Subtleties and episodes in the early life of fishes. J Fish Biol 1989; 35: 29-38.

[9] Oliver JD, Holeton GF, Chua KE. Overwinter mortality of fingerling smallmouth bass in relation to size, relative energy stores, and environmental temperature. Trans Am Fish Soc 1979; 108: 130-6.

[10] Toneys ML, Coble DW. Size-related, first winter mortality of freshwater fishes. Trans Am Fish Soc 1979; 108: 415-9.

[11] Adams SM, McLean RB, Huffman MM. Structuring of a predator population through temperature-mediated effects on prey availability. Can J Fish Aquat Sci 1982; 39: 1175-84.

[12] Miranda LE, Hubbard WD. Length-dependent winter survival and lipid composition of age-0 largemouth bass in Bay Springs Reservoir, Mississippi. Trans Am Fish Soc 1994; 123: 80-7.

[13] Ludsin SA, Devries DR. First-year recruitment of largemouth bass: the interdependency of early life stages. Ecol Appl 1997; 7: 102438.

[14] Fullerton AH, Garvey JE, Wright RA, Stein RA. Overwinter growth and survival of largemouth bass: interactions among size, food, origin, and winter severity. Trans Am Fish Soc 2000; 129: 112.

[15] Post JR, Evans DO. Size-dependent overwinter mortality of youngof-the-year yellow perch (Perca flavescens): laboratory, in situ enclosure, and field experiments. Can J Fish Aquat Sci 1989; 46: 1958-68.

[16] Garvey JE, Wright RA, Stein RA. Overwinter growth and survival of age-0 largemouth bass (Micropterus salmoides): revisiting the role of body size. Can J Fish Aquat Sci 1998; 55: 2414-24.

[17] Santucci VJ, Jr., Wahl DH. The effects of growth, predation, and first-winter mortality on recruitment of bluegill cohorts. Trans Am Fish Soc 2003; 132: 346-60.

[18] Cargnelli LM, Gross MR. The temporal dimension in fish recruitment: birth date, body size, and size-dependent survival in a sunfish (bluegill: Lepomis macrochirus). Can J Fish Aquat Sci 1996; 53: 360-7.

[19] Garvey JE, Herra TP, Leggett WC. Protracted reproduction in sunfish: the temporal dimension in fish recruitment revisited. Ecol Appl 2002; 12: 194-205.

[20] Shoup DE, Wahl DH. Body size, food, and temperature affect overwinter survival of age-0 bluegills. Trans Am Fish Soc 2011; 140: 1298-304.

[21] Johnson TB, Evans DO. Behaviour, energetics, and associated mortality of young-of-the-year white perch (Morone americana) and yellow perch (Perca flavescens) under simulated winter conditions. Can J Fish Aquat Sci 1991; 48: 672-80.

[22] Bernard G, Fox MG. Effects of body size and population density on overwinter survival of age-0 pumpkinseeds. North Am J Fish Manage 1997; 17: 581-90.

[23] Post JR, Parkinson EA. Energy allocation strategy in young fish: allometry and survival. Ecology 2001; 82: 1040-51

[24] Fitzgerald DG, Forney JL, Rudstam LG, Irwin BJ, VanDeValk AJ. Gizzard shad put a freeze on winter mortality of age-0 yellow perch but not white perch. Ecol Appl 2006; 16: 1487-501.

[25] Kaemingk MA, Jolley JC, Willis DW, Chipps SR. Priority effects among young-of-the-year fish: reduced growth of bluegill sunfish
(Lepomis macrochirus) caused by yellow perch (Perca flavescens)? Freshw Biol 2012; 57: 654-65.

[26] Kaemingk MA, Willis DW. Mensurative approach to examine potential interactions between age-0 yellow perch (Perca flavescens) and bluegill (Lepomis macrochirus). Aquat Ecol 2012; 46: 353-62.

[27] Jolley JC, Willis DW, Holland RS. Match-mismatch regulation for bluegill and yellow perch larvae and their prey in Sandhill lakes. J Fish Wildl Manage 2010; 1: 73-85.

[28] Sogard SM, Olla BL. Endurance of simulated winter conditions by age-0 walleye pollock: effects of body size, water temperature and energy stores. J Fish Biol 2000; 56: 1-21.

[29] Jolley JC. Recruitment of bluegill and yellow perch in Nebraska Sandhills lakes: integrating multiple lifestages. PhD dissertation. Brookings: South Dakota State University 2009.

[30] Bleed A, Flowerday C. Introduction. In: Bleed A, Flowerday C, Eds. An Atlas of the Sand Hills. Lincoln: University of NebraskaLincoln 1989; pp.1-15.

[31] Coulter DP, Jolley JC, Edwards KR, Willis DW. Common carp (Cyprinus carpio) population characteristics and recruitment in two Nebraska Sandhill lakes. Trans Nebraska Acad Sci 2008; 31: 3541.

[32] Wanner GA, Nenneman MP, Lindvall M, Kaemingk MA. Common carp abundance, biomass, and removal from Dewey and Clear lakes on the Valentine National Wildlife Refuge: does trapping and removing carp pay off?: Pierre; South Dakota: U.S. Fish and Wildlife Service 2009; pp.14

[33] Greenbank J. Limnological conditions in ice-covered lakes, especially as related to winter-kill of fish. Ecol Monogr 1945; 15: 34392.

[34] Barica J, Mathias JA. Oxygen depletion and winterkill risk in small prairie lakes under extended ice cover. J Fish Res Board Can 1979; 36: 980-6.

[35] Brown ML, St. Sauver T. An assessment of yellow perch, Perca flavescens, stocking contributions in eastern South Dakota lakes. Fish Manage Ecol 2002; 9: 225-34.

[36] Longhenry CM. Yellow perch production in semi-permanent wetlands in eastern South Dakota and evaluation of a new chemical marking tool for juvenile yellow perch.MSc thesis. Brookings: South Dakota State University 2006; p.111

[37] SAS Institute, Inc. SAS/STAT User's Guide, Version 9.1 Edition: Cary, South Carolina; SAS Institute, Inc 2002.

[38] Ricker WE. Effects of size-selective mortality and sampling bias on estimates of growth, mortality, production, and yield. J Fish Res Board Can 1969; 26: 479-541.

[39] Hurst TP, Conover DO. Winter mortality of young-of-the-year Hudson River striped bass (Morone saxatilis): size-dependent patterns and effects on recruitment. Can J Fish Aquat Sci 1998; 55: 1122-30.

[40] Chambers JM, Cleveland WS, Kleiner B, Tukey, PA. Graphical Methods for Data Analysis. Boston, Massachusetts: Duxbury Press 1983; p. 395.

[41] Radke RJ, Eckmann R. First-year overwinter mortality in Eurasian perch (Perca fluviatilis L.): results from a field study and a simulation experiment. Ecol Freshw Fish 1998; 8: 94-101.

[42] Braaten PJ, Guy CS. First-year growth, condition, and sizeselective winter mortality of freshwater drum in the lower Missouri River. Trans Am Fish Soc 2004; 133: 385-98.

[43] Eckmann R. Overwinter changes in mass and lipid content of Perca fluviatilis and Gymnocephalus cernuus. J Fish Biol 2004; 65: 1498-511.

[44] Divino JN, Tonn WM. Effects of reproductive timing and hatch date on fathead minnow. Ecol Freshw Fish 2007; 16: 165-76.

[45] Nasmith LE, Tonn WM, Paszkowski CA, Scrimgeour GJ. Effects of stocked trout on native fish communities in boreal foothills lakes. Ecol Freshw Fish 2010; 19: 279-89.

[46] Pearson RK. Exploring Data in Engineering, the Sciences, and Medicine. New York: Oxford University Press 2011; p. 792.

[47] DeAngelis DL, Coutant CC. Growth rates and size distributions of first-year smallmouth bass populations: some conclusions from experiments and a model. Trans Am Fish Soc 1979; 108: 137-41.

[48] Keast JA, Eadie JMCA. Growth in the first summer of life: a comparison of nine co-occurring fish species. Can J Zool 1984; 62: 1242-50. 
[49] Wismer DA, DeAngelis DL, Shuter BJ. An empirical model of size distributions of smallmouth bass. Trans Am Fish Soc 1985; 114: 737-42.

[50] DeAngelis DL, Huston MA. Effects of growth rates in models of size distribution formation in plants and animals. Ecol Model 1987; 36: 119-37.

[51] Nielsen LA. Effect of walleye (Stizostedion vitreum vitreum) predation on juvenile mortality and recruitment of yellow perch (Perca flavescens) in Oneida Lake, New York. Can J Fish Aquat Sci 1980; 37: 11-9.

[52] Suthers IM, Gee JH. Role of hypoxia in limiting diel spring and summer distribution of juvenile yellow perch (Perca flavescens) in a prairie marsh. Can J Fish Aquat Sci 1986; 43: 1562-70.

[53] Pierce CL, Sexton ME, Pelham ME, Larscheid JG. Short-term variability and long-term change in the composition of the littoral zone fish community in Spirit Lake, Iowa. Am Midl Nat 2001; 146: 290-9.

[54] Collingsworth PD, Kohler CC. Abundance and habitat use of juvenile sunfish among different macrophyte stands. Lake Res Manage 2010; 26: 35-42.

[55] Weber MJ, Brown ML. Diel and temporal habitat use of four juvenile fishes in a complex glacial lake. Lake Res Manage 2012; 28: $120-9$.

[56] Sogard SM. Size-selective mortality in the juvenile stage of teleost fishes: a review. Bull Mar Sci 1997; 60: 1129-57.
[57] Litvak MK, Leggett MK. Age- and size-selective predation on larval fishes: the bigger-is-better hypothesis revisited. Mar Ecol Prog Ser 1992; 81: 13-24.

[58] Post JR, Prankevicius AB. Size-selective mortality in young-of-theyear yellow perch (Perca flavescens): evidence from otolith microstructure. Can J Fish Aquat Sci 1987; 44: 1840-7.

[59] Paukert CP, Willis DW. Factors affecting panfish populations in Sandhill lakes. Lincoln, NE, USA, Completion Report, Federal Aid in Sportfish Restoration Project Number F-118-R, Job Number 1, Segments 1 and 2: Lincoln; Nebraska Game and Parks Commission 2000; p. 75.

[60] Jolley JC, Albin ES, Kaemingk MA, Willis DW. A survey of aquatic invertebrate communities in Nebraska Sandhill lakes reveals potential alternative ecosystem states. J Fish Wildl Manage 2013; 4: 151-62.

[61] Schael DM, Lars GR, John RP. Gape limitation and prey selection in larval yellow perch (Perca flavescens), freshwater drum (Aplodinotus grunniens), and black crappie (Pomoxis nigromaculatus). Can J Fish Aquat Sci 1991; 48: 1919-25.

[62] Bremigan MT, Stein RA. Gape-dependent larval foraging and zooplankton size: implications for fish recruitment across systems. Can J Fish Aquat Sci 1994; 51: 913-22.

[63] Truemper HA, Lauer TE. Gape limitation and piscine prey sizeselection by yellow perch in the extreme southern area of Lake Michigan, with emphasis on two exotic prey items. J Fish Biol 2005; 66: 135-49.

() Jolley et al.; Licensee Bentham Open.

This is an open access article licensed under the terms of the Creative Commons Attribution Non-Commercial License (http://creativecommons.org/licenses/ by-nc/3.0/) which permits unrestricted, non-commercial use, distribution and reproduction in any medium, provided the work is properly cited. 